\begin{tabular}{c|c|c}
\hline \hline & CLIMATE RESEARCH \\
Vol. 22: 87-95, 2002 & Clim Res & Published August 8 \\
\hline
\end{tabular}

\title{
Picturing climate change
}

\author{
Stefan Brönnimann* \\ Institute of Geography, University of Bern, Hallerstr. 12, 3012 Bern, Switzerland \\ and \\ Lunar and Planetary Laboratory, Department of Planetary Sciences, University of Arizona, PO Box 210092, \\ Tucson, Arizona 85721-0092, USA
}

\begin{abstract}
The debate on climate change and anthropogenic influence on climate has a long history, which involves more than just scientific findings and meteorological observations. In this paper, the question of how the scientific concept of climate change has been communicated to the public, in the past and at present is studied using pictures and historical analyses. Publications popularising climate change today are sometimes illustrated with pictures showing palm trees and glaciers together in one scene. This is nothing new: the motif of palm trees and glaciers was used for the same purpose early in the 20th century. Several examples of such illustrations are presented and discussed in a historical context. The basic meaning of such pictures is that palms stand for warm climate and glaciers for coldness, and both together signify climatic change. The use of this motif to illustrate climate change originates in the popularisation of the theory of ice ages and climates in Earth's history, which took place towards the end of the 19th century. At about the same time, the motif of palms and glaciers was also used in tourist advertisement for certain alpine destinations. In this case, the motif stands for the variety of the alpine landscapes, which offer spectacular high-mountain scenery and exotic flora close to each other. It is suggested that the use of this motif to illustrate climate change in the early 20th century expresses an ambivalence towards climate change, consisting of age-old concerns about extremes of climate on the one hand and tourist illusions of a warm climate on the other. Towards the end of the 20th century, the motif appears in context with the popularisation of the concept of anthropogenic global warming. The ambivalence has given rise to a clear negative value judgement. Today, photos of recent extreme weather events are used more often than palm trees and glaciers to illustrate climate change.
\end{abstract}

KEY WORDS: Climate change $\cdot$ Climate and society $\cdot$ History of climate research Resale or republication not permitted without written consent of the publisher

\section{INTRODUCTION}

The possibility of future climatic changes and man's interference with climate are not new topics. Concerns of this kind are deep-rooted in our cultures (Glacken 1967, Fleming 1998). As a consequence, many aspects of the current debate on climate change and global warming are not unprecedented but have a history of their own. This concerns not only the scientific concepts involved. There is also a history of the public perception of the scientific climate debate, of the attitudes towards human intervention with climate, of the value judgements attributed to expected climatic changes

*E-mail: stefanb@lpl.arizona.edu and of the economical, social, and political relevance admitted to the topic. Climate researchers should be aware of these histories, especially when communicating their 'scientific views' to the public.

A number of authors have discussed historical aspects of the climate change debate in detail and from different viewpoints (e.g. Glacken 1967, Grove 1995, Fleming 1998, Pfister 1999, Stehr \& von Storch 2000, von Storch \& Stehr 2000a,b, Glaser 2001). In this contribution I would like to shed light on one often neglected aspect of the history of the climate change debate, namely how the scientific concept of climate change has been communicated to the public in the past and how it is presently. This is studied from a historical perspective and by looking at illustrations, 
which often accompany popularising scientific texts in the print media. Illustrations are particularly interesting sources because they are part of the interface between science and the public. Rebetez (1996) also used illustrations to demonstrate that the public awareness of climate change (such as the notion that, in Switzerland, a white Christmas has become rare) is largely based on expectations (which in this case could have originated from Christmas cards). In the present paper, the motif of 'palm trees and glaciers', which is often used to illustrate the climate change issue in print media, is investigated in more detail.

The motif of palm trees and glaciers can be traced back to the 19th century. It is therefore important to first give a short overview of the history of research on and public perception of climate change and the anthropogenic climate influence up to the end of the 19th century (Section 2). In Section 3, 2 examples of illustrations with palm trees and glaciers are described, one from the year 1919, the other from 1993. A history of the motif of palms and glaciers is given in Section 4 and related to the history of climate research and the popularisation of its main concepts. In Section 5 explanations are sought as to why the motif has been chosen, and the main differences between the 1919 example and the 1993 example are discussed. Conclusions are drawn in Section 6.

\section{CLIMATE CHANGE RESEARCH AND PUBLIC PERCEPTION OF CLIMATE CHANGE UNTIL 1900}

\subsection{Climate change research}

The questions of whether and how climate changes and whether and how man influences climate have been debated by scientists at least since Theophrastus in the 4th century B.C. His works were translated to Latin in the Renaissance period and were influential to the thinking of scientists at that time. Two importantrelated-lines of debate in the discussion on climatic change up into the 19th century concerned the impact of land-use changes on climate and progressive climate changes. In the early and mid 18th century, climate change was a subject treated by the philosophers of the enlightenment period such as Montesquieu and Hume (Glacken 1967, Fleming 1998). More scientific approaches to climate change research started in the second half of the 18th century, in line with efforts in agricultural, forestry and medical research and further advanced by scientific travelling and exchange and the availability of meteorological instruments (see Glacken 1967, Grove 1995). Often triggered by the occurrence of an extreme event (Glaser 2001), present and past climate variability was studied based on proxy and documentary data and observational evidence. Several authors compared the climate of the Mediterranean region during the antique period to the present climate. Mann (1790), for instance, made such a comparison based on written sources. He found that climate has become progressively warmer and drier since that time, which he could not explain by land-use changes. Others did not support the idea of progressive climate change. Ideler (1832) criticised Mann in being too trustful in his documentary sources (a similar controversy took place in America between Webster and Williams, see Fleming 1998). Schouw (1827a,b) found no indication for a changing climate in meteorological observations and other data from Denmark and Scandinavia. Other authors claimed to have proved climatic changes in historical times. The number of scientific studies on climate change in historical times grew rapidly, yet, the results were controversial. During the 19th century, climatic change was the topic of a large number of review papers, books, scientific conferences and text compilations (for Europe, see Ideler 1832, Studer 1847, Arago 1858a,b, Dufour 1870, Polluge 1880, Günther 1886, Brückner 1890, Hann 1897).

A very important step in the history of climate research was the theory of ice ages. Although the time scales involved were longer than those addressed in most of the above-mentioned studies, the existence of ice ages in former times had important implications for climate research in general. It required mechanisms able to explain a large change in mean temperature. This challenge was a trigger for many climate change theories, some of which have influenced the discussion until today (for a contemporary view see Hann 1897). One of these theories concerned changes in the Earth's orbital parameters, which influence the climate of certain regions of the globe, eventually causing ice ages. This theory was discussed in the 19th century by Adhémar, later by Croll (1875) and finally by Milutin Milankovich during the 1930s. The theory of the $\mathrm{CO}_{2}$ greenhouse effect also originated, at least partly, in the debate on the causes of ice ages. Arrhenius (1896) and others speculated that a lower concentrations of atmospheric carbon dioxide could have caused ice ages.

The processes considered in the 19th century to cause shorter-term climate changes were mainly solar influences and anthropogenic activity, but volcanic forcing and changes in ice sheets or ocean currents were also discussed. To start with the natural forcings, the relation between sunspots and climate was first investigated by Herschel (1801) and was a matter of speculation throughout the 19th century (e.g. Cobb 1879); it remains unsolved even to the present day (Svensmark \& Friis-Christensen 1997). The volcanic effect on weather and climate was noticed in the 18th century. 'Strange fogs' leading to cool weather in 
Europe in 1783 were attributed to the eruption of the volcano Laki on Iceland (Franklin 1784). More scientific studies on the volcanic influence on climate were performed after the eruptions of Karakatoa, Indonesia, in 1883 and Katmaï, Alaska, USA, in 1912. The oceans were recognised as a part of the climate system, to which the atmosphere reacts (e.g. Croll 1875). It was believed that changes in the Greenland ice sheet and in Atlantic Ocean currents would affect the European climate (Gilbert 1819, see also Günther 1886).

Among the anthropogenic influences on climate, the oldest topic is the effect of land-use changes, which goes back to Theophrastus in ancient Greece. His work was known to Columbus and his contemporaries, and the 'desiccation theory' (deforestation leads to a drier climate) appears in the scientific literature frequently from the late 17th century, first in the context of tropical island colonies (Grove 1995). Land-use change was suspected to have caused regional-scale climatic changes in the context of the colonisation of North America (e.g. Williamson 1771, Jefferson 1787, Volney 1803). The debate on this topic became more and more popular during the 19th century (e.g. Boussingault 1837, Fischer 1879, Ebermayer 1884, see also reviews by Günther 1886, Brückner 1890), when in many European countries deforestation and reforestation became politically relevant (see also Pfister \& Brändli 1999).

Effects of anthropogenic fuel combustion on weather and climate have been considered since the 19th century. Arago (1858a) noted that at Manchester, due to industrialisation, it almost always rains. An effect of biomass burning in Africa on cloud formation and precipitation was discussed by von Danckelman (1884). Finally, the greenhouse effect of atmospheric carbon dioxide was not only considered to have caused ice ages, as mentioned above. Arrhenius (1896) also calculated the effect of a doubling of atmospheric $\mathrm{CO}_{2}$ and mentioned the burning of fossil fuels as a potential source.

By the end of the 19th century, the debates about climate change and anthropogenic influence on climate culminated in a vivid discussion of the causes of the ice ages, the nature of historical climate variability, the possible human influence on future climate, and also the impact of climate change on the evolving economies and societies. The discussion was not confined to the scientific community, but also included political institutions and was carried out in public (see Stehr \& von Storch 2000, Brückner 1890).

\subsection{Public perception of climate change and anthropogenic influence on climate}

The question of whether climate is changing and whether man is influencing climate is not only or not primarily a scientific one. Climate has always been a matter of vital interest to agricultural societies, and so have changes in climatic conditions. However, climate change cannot be perceived by individuals and therefore gives rise to speculation and imagination (see Rebetez 1996, as mentioned in Section 1). Or, climate change is tied to extreme events, for which there is a longer societal memory (Pfister 1999, Glaser 2001). Concerning the causes for climatic changes, there has always been the notion in the public that man influences climate (see also von Storch \& Stehr 2000a,b). It was familiar to the people in medieval times. For example, extreme weather events were perceived as punishment, and prayers and ceremonies were believed to please God so as to make the weather favourable. Witches were thought to be able to change weather. After the Enlightenment period and during industrialisation, anthropogenic climate change appears in the public in relation to diffuse concerns (see also von Storch \& Stehr 2000a). A nice example relates to the 'year without a summer', 1816, when in Switzerland some people blamed the modern lightning conductors for causing the endless rainfalls, leading even to governmental intervention (Anonymous 1816a,b,c). In these cases the anthropogenic influence was not real, and the people were led by religious or mystic beliefs or simply by superstition and fears, not by scientific arguments. Contemporary scientists, besides, had no explanation to offer for the 'year without a summer'. Apart from some scattered quotes in newspaper reports, there is little indication of a representation of the scientific view of climate change in the public at that time. A public perception of the scientific debate on climate change started only later, probably towards the end of the 19th century (Section 4 will be more specific with regard to this point). Nevertheless, these examples reveal that there are 'age-old concerns about extremes of climate [which] are part of the cultural background, for scientists as well as for the public' (von Storch \& Stehr 2000b, see also Glacken 1967, Fleming 1998). These concerns may also play a role in the current debate on climate change, i.e. the way it is communicated by scientists and activist groups as well as the way it is understood by the public.

\section{TWO EXAMPLES OF ILLUSTRATIONS OF 'PALM TREES AND GLACIERS'}

In this section, 2 examples where 'palm trees and glaciers' have been used to illustrate popular-scientific publications about climatic change are discussed. The 2 examples are separated by several decades. The motif was used nearly a century ago to communicate the climate change issue to the public. And it is still in use today! 

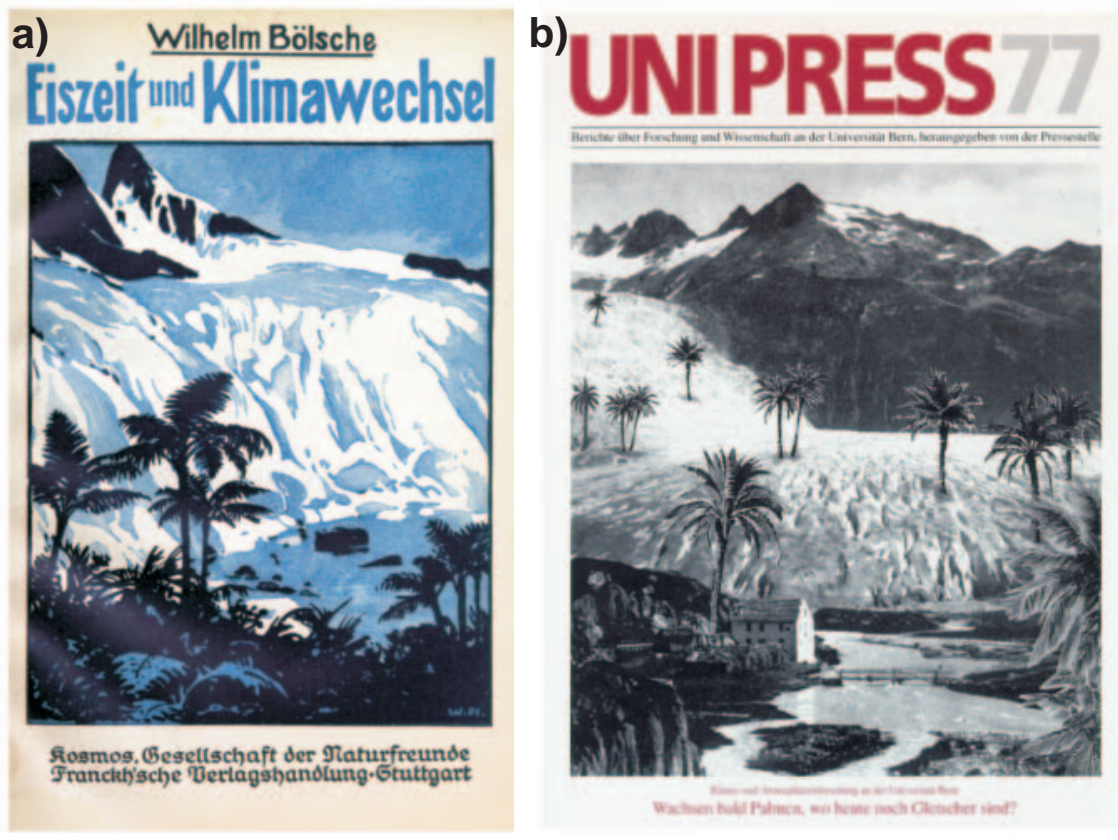

Fig. 1. (a) Title page of a popular-scientific booklet, 'Ice age and climate change', Kosmos Verlag, 1919, printed in two colours, $13.3 \times 10.5 \mathrm{~cm}$. (b) Title page of a special issue on climate research of the magazine of the University of Bern, 1993, photo/collage, $22.0 \times$ $18.9 \mathrm{~cm}$
The first example in Fig. 1a is the coloured title page of a popular-scientific booklet entitled 'Eiszeit und Klimawechsel' (Ice age and climate change), printed in 1919. The booklet was published by the 'Kosmos Gesellschaft der Naturfreunde', a society for laypeople interested in sciences. The author, who had already published 2 other booklets in the same series (on natural history topics), describes the scientific debate about the nature and causes of ice ages and other climate changes, as described in Section 2. The booklet focuses on the past, but possible future climate changes are also discussed, including the anthropogenic greenhouse effect. Although the booklet was not written for scientists, the author represents the scientific view. He has a critical attitude towards many of the ice age theories, but he also expresses his personal fascination for climate research.

The title page (the artist is unknown) is a Jugendstil (Art Nouveau) graphic with 2 printed colours (blue and black), but the white colour of the paper also plays an important role for obtaining the effect of light and shadow. The picture shows palm trees in the foreground against the light and a glacier as a bright, large mass of torn ice in the background. A mountain peak and a rocky slope form the horizon. An adaptation of this picture as a small black line drawing appears on the cover page of the booklet. A line drawing of the title page is also printed in black in the publisher's advertisements.

The second image is a title page of a magazine published by the press office of the University of Bern. This publication also aims at attracting people outside the university and the scientific community. The title page illustrated a special issue on climate change science at the University of Bern, consisting of a number of short articles in newspaper style. The articles encompass past and present climate changes, including anthropogenic climate change. The picture is a collage by Christine Baser. It is based on a photo of the Rhone glacier which is published in one of the articles of the issue (Baumgartner et al. 1993). The photo (Alpine Club Library, London) was taken by F. Martens around 1856 , i.e. at the time of the last maximum of this glacier. On the title page, palm trees are pasted onto the photo, which, except for the one in the lower right corner, stem from low-quality line drawings. The trees are attached at different places from the foreground to the background. The caption states (translated): 'Climate and atmospheric research at the University of Bern' and then in larger letters 'Will palm trees soon grow where there are still glaciers today?'

The main relation of palm trees and glaciers to climate is clear and can be understood by everyone. Palm trees symbolise warm climate, and glaciers stand for coldness; both together in one scene signify climatic changes. Joining objects that in reality do not occur together is a common illustration technique. The presence of 2 dichotomous symbols in one picture produces astonishment or puzzle. It may be assumed that such a puzzling effect was intended.

There are obvious visual similarities between the two pictures. Palms are in the foreground, a glacier in the mid-ground and rocky mountain peaks in the background. Both pictures were designed to illustrate popular-scientific texts on climate change and climate variability. But there are also differences. In the picture 
from 1919, the distance and contrast between palms and glaciers is large, so that despite the obvious dichotomy, the scene does not appear completely unreal. There is even harmony, majesty and quietness in this picture. The picture from 1993, in contrast, gives the impression of surreality and restlessness. This is accentuated by the fact that the palm trees are attached directly on the ice, where they cannot possibly grow. Also, the contrast between the low-quality line drawings and the photo produces an unreal scene.

\section{HISTORY OF THE MOTIF 'PALM TREES AND GLACIERS'}

There is more behind palm trees and glaciers than just the meaning of warmth and coldness. In this section, I discuss the origin of this motif and its use in the context of climate change.

\subsection{Palm trees or leaves}

Palm trees are an old symbol known from Mediterranean cultures but they are also a Jewish-Christian symbol having different meanings. Palm trees (date palms) were important to the people living in the arid regions of the southern Mediterranean. Since the occurrence of date palms (or, more precisely, the ability of dates to ripen) has a geographical limit which depends on temperature, their distribution is an indicator of climate. This has been recognised long ago, and the distribution of date palms was used in many early paleoclimatological studies (e.g. Ideler 1832, Arago 1858b). Palms were therefore also a study object in climate research. The same is true, to some extent, for fossil palm leaves in natural history research. Many scientists interpreted fossil palm leaves found in temperate latitudes to be an indicator of past climate changes (e.g. Ideler 1832 and references therein), although this problem was far from being solved prior to the concept of plate tectonics.

\subsection{Glaciers}

Scientific studies on glaciers began in the 18th century (Zumbühl \& Iken 1981). Concurrently, glaciers also became a popular motif for proto-romantic and romantic painters in the late 18th and 19th centuries (Zumbühl 1983) in the context of the 're-discovery of nature'. Even more than palm trees, glaciers have been and are still a popular study object in climate research. Changes in the length or mass of glaciers - measured or reconstructed from written sources, pictures, and geomorphological or paleobotanical evidence-can indicate past climate changes. In this context, an early research programme initiated by the 'Schweizerische Gesellschaft für die Naturwissenschaften' (Swiss Academy of Sciences) from 1817 to 1821 investigated whether the often claimed 'recent climate change in the Alps' was true or not (Usteri 1817). Glacier movements were intensively studied in this context, together with many other sources of information (Kasthofer 1822, Venetz 1833).

These studies and work by other authors, eventually led to the discovery of ice ages, which was undoubtedly a milestone in the history of climate change research and its public awareness. Louis Agassiz completed the theory of ice ages and became famous with his glaciological field work. This research, as well as the partly controversial debate, was perceived even outside the scientific community, at least in Switzerland. Although the ice age theory was still scientifically debated, the question of ice ages soon found its way into the standard textbooks for higher education (e.g. Studer 1847). A very important work with regard to the popularisation of the ice age theory and other climate changes in Earth's history was the standard textbook by Heer (1865) on the natural history of Switzerland. It not only presented fossil palm leaves as evidence for warmer climate, but also discussed the ice ages. The latter part was accompanied by an illustration, 'Zürich zur Gletscherzeit' (Fig. 2). This figure shows the loca-

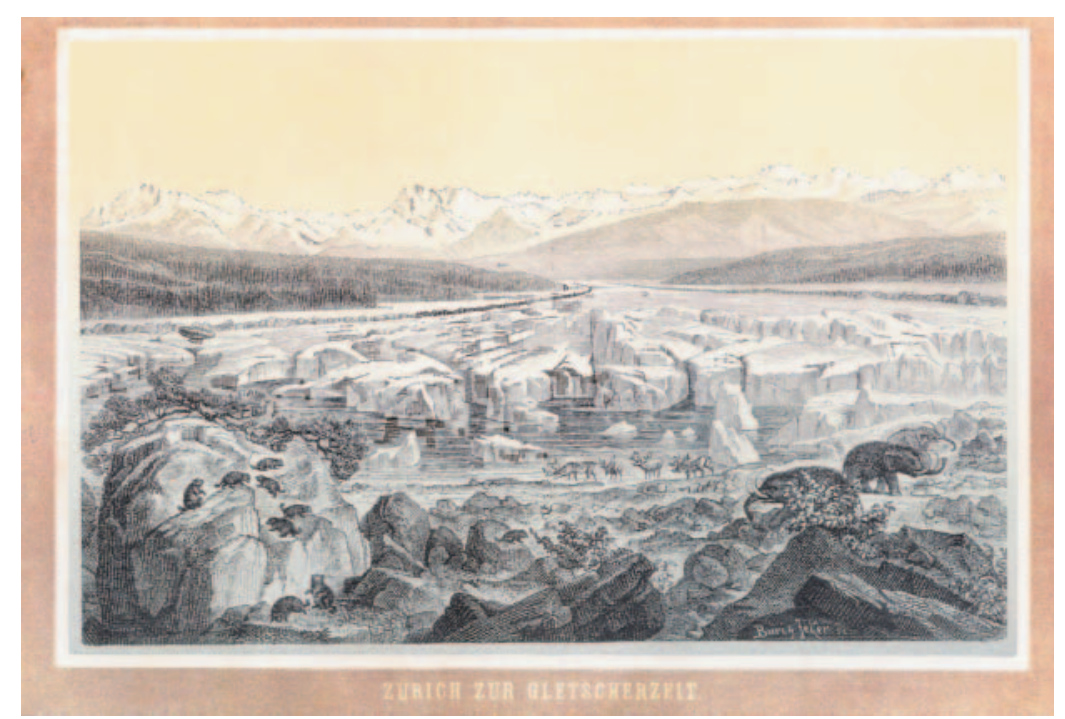

Fig. 2. 'Zürich zur Gletscherzeit' (Zürich during the glacial epoch), coloured xylography, $10.9 \times 16.9 \mathrm{~cm}$ (without frame), by Buri \& Jeker, published in Heer (1865) 
tion of the city of Zurich as it must have looked during the ice ages. The picture is dominated by a huge glacier. In the foreground, the supposed flora and fauna of the ice age period is set in scene, mountain peaks are visible in the background. The view from Zurich towards the Alps was familiar to many of the readers. For them, this illustration made the scientific concept of ice ages appear more real.

The spreading of the ice age theory to the public consciousness was further accelerated, for the case of Switzerland, by the discovery of glacial potholes in Lucerne, far away from present-time glaciers. By private initiative, the rock was turned into a museum called 'Gletschergarten' (Glacier Garden), which presented its visitors hard evidence for the existence of glaciers at Lucerne in former times. It was opened to the public in 1873 and soon became a popular tourist attraction (Wick 1998). Numerous newspapers reported this sensation and also the scientific background, i.e. the ice age theory. The Glacier Garden became a monument of past climatic changes and played an important role in the popularisation of the scientific concepts of ice ages and climate change. Before the First World War, the number of visitors attained $100000 \mathrm{yr}^{-1}$.

In Switzerland, we can assume that the existence of ice ages was known to a relatively broad public in the early 20th century. This is also reflected in the large number of newspaper reports and in the fact that the term 'ice ages' is mentioned in textbooks for public school (e.g. Hotz 1891).

\subsection{Palms and glaciers}

We do not know when exactly the motif of palm trees or leaves and glaciers was used for the first time. One possible origin leads to the history of the Glacier Garden in Lucerne. A few years after the discovery of the potholes, fossil palm leaves from the Keuper era were found in the same rock. The Glacier Garden also used palms and glaciers in its posters. Fig. 3a shows a poster advertisement for the Glacier Garden, presumably from around 1896. It shows a large number of items which can be seen at the Glacier Garden, among them a painting of a glacier (the Morteratsch glacier) and in the lower right-hand corner the fossil palm leaves. Palms and glaciers appear on this poster in relation to past climate changes. We may term this line of origin the 'natural history origin' of the motif, with Heer's ice age picture being a precursor.

There is also a second line of origin of the motif of palms and glaciers which is not related to climate change. Palm trees are foreign to the flora north of the Alps, but they grow in its southern valleys. Glaciers occur in the high Alps and make an important part of the alpine scenery. The proximity of spectacular highalpine landscapes and the Mediterranean climate and flora became attractive for the Belle Epoque tourism in the late 19th century. The motif of palms and glaciers as an expression for the natural variety of the alpine landscapes and as an attractive contrast was used for advertisement. Fig. 3b shows a poster which advertises the stagecoach service to the region of St. Moritz in the
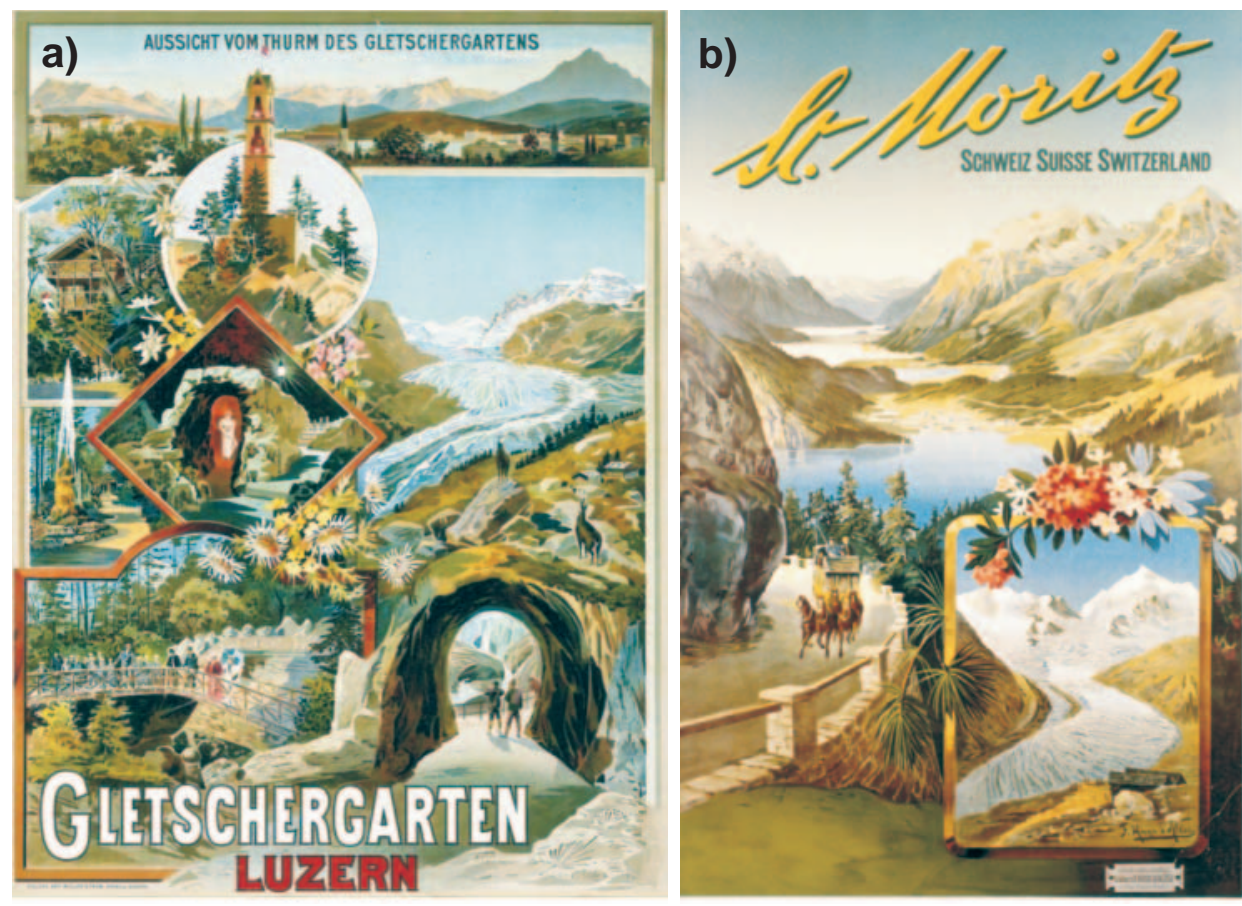

Fig. 3. (a) Poster advertisement for the Glacier Garden, Lucerne. Lithography in colour, $78 \mathrm{~cm} \times 58 \mathrm{~cm}$, by Ateliers Arts Müller \& Trüb, Aarau \& Lausanne, ca. 1896. Archive of Glacier Garden, Lucerne. (b) Poster advertisement for the 'Pferdepost' (service of stagecoaches) for St. Moritz. Lithography in colour, $101.5 \times 64 \mathrm{~cm}$, printed 1895 in Italy. Designed by F. Hugo D'Alési (Ateliers Hugo D'Alési, Paris). PLS Plakatsammlung, Museum für Kommunikation, Bern 
Upper Engadine, printed in 1895. It shows a view of the valley towards the Maloja Pass with a stagecoach (probably on the road from the Julier Pass) with 5 horses in the foreground. On an inset the Morteratsch glacier is shown, and this inset is framed by plants and flowers, among them alpine roses, edelweiss, and palm leaves. In fact, palm trees grow in the Val Bregaglia, a few kilometres downhill from the Maloja Pass in the background of the figure. We may term this the 'tourist line of origin' of the motif.

The 2 posters shown in Fig. 3 look very similar. There is also similarity in their communication: both are poster advertisements, both are designed to attract tourists or visitors, and both promise an experience which is related to nature (see Bosshart-Pfluger 1998 for the experience of visiting the Glacier Garden in the 19th century).

\section{DISCUSSION}

Why was the motif of palms and glaciers chosen to illustrate a popular-scientific booklet on ice ages and climate change in 1919? And what impressions could the reader have had? As mentioned in Section 3, the composition of the picture has a puzzling effect, but it also presupposes some a priori knowledge. Bölsche was not the first to write about ice ages. When his booklet appeared, the existence of ice ages in former times was already known to a relatively broad public. Apart from the effect of the striking contrast between palm trees and glaciers, this general knowledgeeveryone knows about ice ages-is one cause that made and still makes this motif 'telling'. But what does it tell? The awareness of the existence of ice ages in former times was not only important as a trigger for climate research, but also for the public perception. The author of the booklet explains this in the following way (Bölsche 1919, p. 13, followed by translation):

'Immer wieder halten sich alte Überlieferungen, es [das Wetter] sei besser geworden oder es sei schlechter geworden. Es gibt wohl keinen schlichtesten Menschen, der nicht auch nur auf Grund seiner eigenen Lebenserfahrung einmal versucht hat, in das ewig Wechselnde, Chaotische, Unberechenbare dieses Wetters irgendein Gesetz hineinzudeuten. ... In der Eiszeit aber scheinen sich gleichsam alle Wunder dieses Wetters zu vereinigen. Etwas wie eine uralte Volksangst unserer Ahnen scheint darin aufzuleben: vom Weltwinter, der alles vernichtete. Zugleich meint man, wer ihr Geheimnis löste, müsste auch den Wetterzauber von heute in Händen haben.'

'The belief that it [the weather] has improved or worsened in the course of time quite persistently holds up. There is hardly any human being, even the most common, who has not tried, owing to the experiences of his life, to attribute the eternally changing, chaotic, unpredictable character of the weather to some law. ... In the ice age, however, all miracles of this weather seem to unite. Something like an age-old fear of our ancestors seems to come to life again: of a global winter that destroyed everything. At the same time one believes that whoever solved the secret of the ice age would be able to understand the magic of today's weather.'

Bölsche clearly attributes the fascination of ice ages to the afore-mentioned age-old concerns about extremes of climate, and it is natural for him to relate the ice ages to present and future weather (or climate) changes. Despite these fears, climate change is not presented as something entirely negative. There is a strong fascination for the topic, which is discernible throughout the book. And there is a positive value judgement for a change towards a warmer climate. Speculating about the future climate, Bölsche mentions possible palm groves in Germany in the (distant) future. It is interesting that the publisher has chosen this sentence, which has little weight in the book, for the advertisement of the booklet. This is in agreement with the illustration on the title page (Fig. 1a), which leaves space for hopes and illusions related to climate change. Thus, the illustration expresses an ambivalence towards climate change: there are ageold fears about extremes of climate, but there are also tourist illusions of a warm climate.

In fact, 'global warming' has for a long time been considered beneficial to mankind, from the dominating temperate latitude point of view, including the anthropogenic greenhouse effect (e.g. Callendar 1938; but the same is also found in textbooks: Berget 1922). There was not only a positive value judgement, but there were even plans to make the climate warmer (see Wexler 1958). This positive value judgement gave rise to a predominantly negative one only after the 1950s (see also von Storch \& Stehr 2000b). Since the 1970 s, the anthropogenic greenhouse effect has presumably become the most widely known theory on climate change. In the public perception in 1993, when Fig. 1b was published, the theory of the greenhouse warming had in some ways the same position as the ice age theory had at the time of Bölsche. (In many respects, however, this comparison does not hold and we are facing a new situation. Climate observations tell us that the anthropogenic warming is already occurring.) The general knowledge about global warming is what makes the motif of palm trees and glaciers 'meaningful' in 1993. The illustration still represents the same age-old concerns about extremes of climate, but the ambivalence in value judgements is largely lost, although the same motif is still widely used in tourist advertisements. There is no space for tourist illusions in the picture in Fig. 1b. In contrast, the natural variety of the Alpine landscapes turns into vulnerability with respect to future climate scenarios. 
The motif of palms and glaciers is somewhat out of fashion. Today, the climate change issue is illustrated more often with photos of recent extreme weather events. They make allusion to the often heard notion that extreme events have increased in frequency and will further increase in frequency due to climate change. Thus, they imply that we are currently witnessing the start of a new, disastrous climate epoch - of course, the projection of weather extremes into an apocalyptic future climate is not new. The communication is based on the same age-old concerns. It seems that, in the current news market, photos of extreme events sell better than illustrations of a slowly ongoing climate change.

\section{CONCLUSIONS}

The motif of palm trees and glaciers is today often used to illustrate popular-scientific publications on climatic change, but it has already been used for this purpose in the early 20th century. The motif belongs to a mountainous or alpine environment. This concerns not only the scientific concept of climate change, which has a long tradition in the Alps (especially the ice age theory). It concerns also the natural diversity of the alpine landscapes and its attractiveness for tourism.

One can only speculate why the motif of palm trees and glaciers was chosen in the 2 examples presented in this paper. To join objects that in reality do not occur together is an often-used illustration technique. In the case of this motif, however, the technique also reflects age-old concerns about extremes of climate. In the late 19th and early 20th century, these concerns revived in the ice age debate. The awareness of the existence of ice ages in former times was not only a trigger for many climate change theories, including (apart from many rather strange theories) orbital climate forcing and the $\mathrm{CO}_{2}$ greenhouse effect, but also for an increase in the public perception of the climate change issue. Both together were expressed in pictures and motifs such as the ones shown in Fig. 1. Nowadays, the same concerns revive in regard to the scenario of global warming, which is more certain and more immediate than ice ages were 100 yr ago.

Scientists often portray the global warming issue as something unprecedented, and in many respects it certainly is. However, we often forget that the statements of today's climate researchers add to a debate which has been going on for centuries and in which resound many deep-rooted notions.

Acknowledgements. The author is grateful for communications with Dr. Nott Caviezel, Bern, and Prof. Hans von Storch, Hamburg. Dr. Peter Wick, Glacier Garden, Lucerne, assisted in searching the archive and provided a reproduction of the poster displayed in Fig. 3a. The German quotation in Section 5 was translated by Esther Thalmann. Two anonymous reviewers made helpful comments.

\section{LITERATURE CITED}

Anonymous (1816a) Untitled, NZZ (Neue Zürcher Zeitung) 21 June and 9 July, Zurich (reprinted in Wanner H, Gyalistras D, Luterbacher J, Rickli R, Salvisberg E, Schmutz C (2000) Klimawandel im Schweizer Alpenraum. vdf Verlag an der ETH Zürich, Zürich)

Anonymous (1816b) Vom Wetter und Wetterpropheten. Schweizerfreund 2:218

Anonymous (1816c) Fernere Wetter-Erklärung. Schweizerfreund 2:225-226

Arago F (1858a) Notes scientifiques sur la prédiction du temps. Oeuvres complètes, Vol 8. Gide, Paris, p 1-24

Arago F (1858b) L'Etat thermométrique du globe terrestre. Oeuvres complètes, Vol 8. Gide, Paris

Arrhenius S (1896) On the influence of carbonic acid in the air upon the the temperature of the ground. Philos Mag J Sci Ser 5 41:237-276

Baumgartner M, Rickli R, Zumbühl H, Wanner H (1993) Zur Klimadynamik der Alpen. Unipress (University of Bern) $77: 22-30$

Berget A (1922) Les problèmes de l'atmosphère. Paris

Bölsche W (1919) Eiszeit und Klimawechsel. Kosmos Gesellschaft der Naturfreunde, Franckh'sche Verlagsbuchhandlung, Stuttgart

Bosshart-Pfluger C (1998) Das 'Erlebnis Gletschergarten' im 19. Jahrhundert. Proseminararbeit am Institut für Zeitgeschichte der Universität Freiburg, Freiburg

Boussingault M (1837) Mémoire sur l'influence des défrichements dans la diminution des cours d'eau. Ann Chim Phys 64:113-141

Brückner E (1890) Klimaschwankungen seit 1700 nebst Bemerkungen über die Klimaschwankungen der Diluvialzeit. Wien

Callendar GS (1938) The artificial production of carbon dioxide and its influence on temperature. Q J R Meteorol Soc 64:223-241

Cobb F (1879) Sun-spots and the Nile. Nature 19:299-300

Croll J (1875) Climate and time in their geological relations. London

Dufour L (1870) Notes sur le problème de la variation du climat. Bull Soc Vaudoise Sci Nat 10(63):360-436

Ebermayer E (1884) Über den Einfluss des Waldes auf den Regen. Z Österreich Ges Meteorol 19:288-290

Fischer T (1879) Studien über das Klima der Mittelmeerländer. Ergänzungsheft Petermann's Mitt 58:1-46

Fleming JR (1998) Historical perspectives of climate change. Oxford University Press, New York

Franklin B (1784) Meteorological imaginations and conjectures. Mem Lit Phil Soc Manchester 2:373-377

Gilbert LW (1819) Physikalisch Geographische Nachrichten aus dem nördlichen Polarmeer. Als Anhang zu den Aufsätzen im vorigen Hefte. Gilbert's Ann (Ann Phys) 62:137-166

Glacken C (1967) Traces on the Rhodian shore: nature and culture in western thought from ancient times to the end of the eighteenth century. University of California Press, Berkeley

Glaser R (2001) Klimageschichte Mitteleuropas. 1000 Jahre Wetter, Klima, Katastrophen. Primus Verlag, Darmstadt

Grove RH (1995) Green imperialism: colonial expansion, trop- 
ical island Edens and the origins of Environmentalism, 1600-1860. Cambridge University Press, Cambridge Günther S (1886) Lehrbuch der Geophysik, Vol 2. Stuttgart Hann J (1897) Handbuch der Klimatologie, Vol 1: Allgemeine Klimatologie, 2nd edn. Verlag J. Engelhorn, Stuttgart

Heer O (1865) Die Urwelt der Schweiz. F. Schulthess, Zürich Herschel W (1801) Observations tending to investigate the nature of the sun, in order to find the causes or symptoms of its variable emission of light and heat; with remarks on the use that may possibly be drawn from solar observations. Phil Trans R Soc Lond 92:265-318

Hotz R (1891) Leitfaden für den Geographieunterricht an Sekundar- und Mittelschulen. Verlag v R Reich, Basel

Ideler JL (1832) Ueber die angeblichen Veränderungen des Klima. Ann Erd- Völker- Staatenkund (Berghaus' Ann) $5: 417-471$

Jefferson T (1787) Notes on the State of Virginia, Electronic Text Center, http://etext.lib.virginia.edu/toc/modeng/public/ JefVirg.html

Kasthofer K (1822) Beiträge zur Beantwortung der von der Schweizerischen Gesellschaft für die Naturwissenschaften aufgeworfenen Frage: 'Ist es wahr, dass die hohen schweizerischen Alpen seit einer Reihe von Jahren wirklich rauher und kälter geworden sind?' In: Kasthofer K (ed) Bemerkungen auf einer Alpenreise. Aarau, 273ff

Mann (Abbé) (1790) Ueber die allmählichen Veränderungen der Temperatur und des Bodens in verschiedenen Climaten, nebst Untersuchungen über die Ursachen dieser Veränderungen. Historia et Commentationes Academiae Theodoro-Palatinat, Vol 6. Physicum Mannheimii, p 82-111 [reprinted in abbreviated form in J Phys (Grens's J) 2: 231-244, 1790]

Pfister C (1999) Wetternachhersage. 500 Jahre Klimavariationen und Naturkatastrophen. Haupt Verlag, Bern

Pfister C, Brändli D (1999) Rodungen im Gerbirge-Überschwemmungen im Vorland: Ein Deutungsmuster macht Karriere. In: Sieferle RP, Breuninger H (eds) Natur-Bilder. Wahrnehmungen von Natur und Umwelt in der Geschichte. Campus Verlag, Frankfurt/Main, p 297-323

Polluge L (1880) Klimaänderungen in historischen Zeiten. Sammlung gemeinverständlicher wiss Vorträge, Ser XV, H 359, Berlin

Rebetez M (1996) Public expectations as an element of human perception of climate change. Clim Change 32:495-509

Editorial responsibility: Hans von Storch, Geesthacht, Germany
Schouw JF (1827a) Vermeintliche Veränderung der klimatischen Verhältnisse Dänemarks. Hertha

Schouw JF (1827b) Beiträge zur vergleichenden Klimatologie. Kopenhagen

Stehr N, von Storch H (2000) Eduard Brückner-the sources and consequences of climate change and climate variability in historical times. Kluwer, Dordrecht

Studer B (1847) Lehrbuch der physikalischen Geographie und Geologie, Vol 2. Bern

Svensmark H, Friis-Christensen E (1997) Variation of comsmic ray flux and global cloud coverage - a missing link in solar-climate relationships. J Atmos Solar-Terr Phys 59: $1225-1232$

Usteri P (1817) Eröffnungsrede, Vol 3. Verhandlungen der Schweizerischen Naturforschenden Gesellschaft

Venetz I (1833) Les variations de la température dans les Alpes de la Suisse. Denkschriften der allgemeinen Schweizerischen Gesellschaft für die gesammten Naturwissenschaften (alte Serie) 1(2):1-38

Volney CF (1803) Tableau du climat et du sol des Etats-Unis d'Amérique, Vol 1. Paris

von Danckelman A (1884) Die Bewölkungsverhältnisse des südwestlichen Afrikas. Z Österreich Ges Meteorol 19:301-311

von Storch H, Stehr N (2000a) Anthropogenic climate change - a reason for concern since the 18th century and earlier. Prace Geogr 108:81-86

von Storch H, Stehr N (2000b) Climate change in perspective. Nature 405:615

Wexler H (1958) Modifying weather on a large scale. Science 128:1059-1063

Wick P (1998) Ausflüge in die Vergangenheit. 125 Jahre Gletschergarten Luzern: Wissenschaft und Erlebnistourismus. Kunst Arch Schweiz 49(2):35-45

Williamson $\mathrm{H}$ (1771) An attempt to account for the change of climate, which has been observed in the Middle Colonies in North-America. Trans Am Phil Soc 1 (Volume reprinted 1789, p 336-345)

Zumbühl H (1983) Gletschergeschichte im Spiegel der Kunst. In: Zumbühl H, Messerli B, Pfister C (eds) Die Kleine Eiszeit. Gletschergarten-Museum Luzern, Schweizerisches Alpines Museum, Bern, p 9-61

Zumbühl H, Iken A (1981) Gletscher der Berner Alpen und ihre Erforschung. Illustrierte Berner Enzyklopädie, Vol 1: Die Natur. Bern, p 54-61

Submitted: November 15, 2000; Accepted: November 4, 2001 Proofs received from author(s): June 22, 2002 